[Research Paper]

\title{
Effect of Individual Differences on Online Review Perception and Usage Behavior: The Need for Cognitive Closure and Demographics
}

\author{
Yoon Jin Ma $\cdot$ Kim Hahn* $\cdot$ Hyun-Hwa Lee** \\ Dept. of Family \& Consumer Sciences, Illinois State University \\ *The Fashion School, Kent State University \\ **Dept. of Fashion Design \& Textiles, Inha University
}

Received August 24, 2012; Revised October 2, 2012; Accepted November 14, 2012

\begin{abstract}
This article examines how individual differences on the need for cognitive closure and demographics influence consumer perception and the usage of consumer reviews in online shopping. Data were randomly collected from 2,381 U.S. online consumer review users through an online survey. The findings from multiple regression analyses revealed the different effects of the need for cognitive closure dimensions (i.e., preference for order and structure, preference for predictability, discomfort with ambiguity, closed-mindedness, and decisiveness) and demographic characteristics on consumer attitudes, perceived online review influence, benefits, persuasiveness, and review usage behavior. Finally, practical implications and prospects for future research are discussed.
\end{abstract}

Key words: Need for cognitive closure, Online reviews, Consumer behavior, Individual difference, Demographics

\section{Introduction}

As online shopping becomes increasingly popular, online consumer reviews have become a new type of word-of-mouth information channel playing a more important role than ever in consumers' purchase decision-making process and product sales. According to the e-tailing group and PowerReviews ("The 2011 social shopping", 2011), approximately $59 \%$ of online shoppers reported that user-generated customer product reviews have a significant or strong impact on their buying behavior ("The 2011 social shopping", 2011). In addition, the Nielsen global online survey company ("Global advertising", 2009) found that $90 \%$ of Internet consumers surveyed trusted recommendations from people they know and 70\% trusted consumer opinions posted online ("Global advertising", 2009).

\footnotetext{
${ }^{\dagger}$ Corresponding author

E-mail: hyunhwa@inha.ac.kr
}

As one of the most trusted forms of advertising, online consumer reviews are a major source of information for consumers' decision making (Chatterjee, 2001; Mudambi \& Schuff, 2010). The consumer decision-making process includes several stages: need recognition, information search, evaluation of alternatives, purchase decision, purchase, and post-purchase (Kotler \& Keller, 2005). After consumers identify a need, they can use reviews written by other consumers to search for information and evaluate alternatives (Mudambi \& Schuff, 2010). However, during this stage, consumers interpret these reviews based on the type of information they want (Houghton \& Grewal, 2000).

The current research study uses need for cognitive closure (NFCC) as an individual characteristic for determining the various ways in which consumer reviews are perceived. Kruglanski and colleagues conceptualized NFCC as an individual's desire for a de- 
finitive answer to a question (Kruglanski \& Webster, 1996; Kruglanski et al., 1997). NFCC influences the way in which people process information prior to making decisions and other buying behaviors (Kruglanski \& Webster, 1996; Lee et al., 2009). Although previous research has demonstrated that online consumer reviews influence consumers' online shopping behaviors and their information search process, little research has focused on individual differences in consumers' perception and usage of consumer reviews in relation to their cognitive processes, especially among online apparel shoppers (Bickart \& Schindler, 2001; Schindler \& Bickart, 2005; Smith et al., 2005). As online shopping has become one of the most popular ways of purchasing apparel products among younger consumers (Case \& King, 2003; Park \& Cho, 2012), it would be beneficial for apparel retailers to understand how online consumers perceive online consumer reviews, particularly those related to apparel products, as online consumers cannot physically try on or feel such products. Compared to online review systems utilized by other general retailers, those used by apparel retailers are rather limited (Lee, 2012). Although this study examined general online shoppers from various online retailers (i.e., not exclusive to online apparel shoppers), we hope to shed light on understanding online apparel shoppers by examining various other online consumers' cognitive process in relation to online consumer reviews.

Therefore, the purpose of this research is to examine the ways in which individual differences in five dimensions of NFCC and demographics influence consumer perception and usage of consumer reviews in the course of online shopping. To avoid potential bias resulting from consumers' previous experience with online reviews, the differences were explored only among respondents who had already used online consumer reviews in their purchase decision making.

\section{Literature Review}

\section{Online Consumer Product and Service Re- views}

Online consumer reviews are peer-generated prod- uct evaluations posted on company or third-party websites (Mudambi \& Schuff, 2010). Prior to making a purchase decision, consumers search for information to reduce perceived risk (Bettman, 1973). The importance of word-of-mouth (WOM) as a source of information that affects consumers' purchase decisions and choice behavior has already been extensively demonstrated in previous studies (e.g., Lau \& Ng, 2001). As more consumers than ever search online for product and service information and evaluate the alternatives, online consumer reviews as one type of electronic WOM (e-WOM) have become an important information channel for reducing consumers' perceived risk of online shopping (Chen \& Xie, 2008). Research has demonstrated that e-WOM communication is as effective as traditional WOM (Goldsmith \& Horowitz, 2006; Gruen et al., 2006; Hennig-Thurau et al., 2004). Online consumer reviews are perceived as more being valuable than expert reviews ("Online consumer-generated reviews", 2007) and having a direct influence on consumer purchase decision (Prendergast et al., 2010) as well as an even greater effect on offline purchase behavior ("Online consumer-generated reviews", 2007). Previous studies have suggested that e-WOM influences consumer online shopping behaviors and has been used as a heuristic in information searches (Bickart \& Schindler, 2001; Smith et al., 2005). However, only a few studies have examined how online review perceptions are influenced by individual characteristics such as cognitive personalization (Xia \& Bechwati, 2008), information processing confidence (Lee \& Ma, 2012), gender (Bae \& Lee, 2011), and Internet experience (Zhu \& Zhang, 2010). Therefore, in the current study, NFCC and demographic characteristics were used to measure the different ways in which shoppers perceive online consumer reviews and how different levels of NFCC affect online consumer review usage among online consumer review users.

\section{Need for Cognitive Closure}

NFCC refers the desire for a clear, definite answer to a question (Kruglanski et al., 1993). When people need to make a decision, the process can depend on their level of NFCC: People with high NFCC repre- 
senting a need to attain cognitive closure will make a quick, firm, and final decision, unlike those with low NFCC (Choi et al., 2008). Previous research has indicated that NFCC influences the way people seek out and elaborate on information prior to forming judgments or making decisions (Kruglanski \& Webster, 1996); it also affects their information process style (Klein \& Webster, 2000; Kruglanski \& Freund, 1983; Kruglanski et al., 1993) and consumer behaviors (Houghton \& Grewal, 2000; Lee et al., 2009). For example, individuals with high NFCC base their judgment on preexisting knowledge structures or inconclusive evidence appearing early in a sequence, making them more reluctant to absorb new information and less willing to spend time and energy processing large amounts of information that could reduce the amount of pre-decision information processing and searching (Houghton \& Grewal, 2000; Kruglanski \& Webster, 1996; Vermeir \& Van Kenhove, 2005). Other studies have shown that individuals with high NFCC are more likely to use heuristics or display heuristic thoughts as well as engage in theory- or category-driven (versus data- or attribute-driven) processing. Furthermore, high-NFCC individuals tend to have a bias toward con- sistency, expressed as a preference for general knowledge that is applicable across situations, over situation-specific knowledge (Vermeir \& Van Kenhove, 2005). Meanwhile, individuals with low NFCC might value or enjoy uncertainty and be reluctant to commit to a definite opinion, try to remain immune to possible criticism of any given closure, and tend to engage in information processing in order to avoid any conclusion (Vermeir \& Van Kenhove, 2005). Based on a review of previous literature, NFCC provides a useful framework for analyzing consumers' informationgathering process, decision-making process, and purchasing behavior (Houghton \& Grewal, 2000). Therefore, it is imperative to study how an individual perceives and processes online consumer reviews according to his or her level of NFCC.

\section{1) Dimensionality of NFCC}

NFCC has been conceptualized in previous studies as (1) a preference for order and structure, (2) a preference for predictability, (3) a discomfort with ambi- guity, (4) closed-mindedness, and (5) decisiveness (e.g., Kruglanski \& Webster, 1996; Mannett et al., 2002; Roets \& Van Hiel, 2007). Although NFCC measures individual differences in each facet and in the tendency toward a person's need for closure, several psychometric studies focusing on NFCC have suggested that the five dimensions do not always relate uniformly to each other or to other constructs; some researchers have used only a certain dimension of NFCC for their studies (e.g., Lee et al., 2009; Neuberg \& Newsom, 1993; Smith \& Gordon, 1998; Thórisdóttir \& Jost, 2011).

Determining the preference for order and structure relies on the need to maintain order and avoid disorder. This dimension has been used to examine the personal need for structure, with the preference for predictability being used to study a wide range of behaviors such as attitudes toward lesbians and gays (Smith \& Gordon, 1998), gender stereotyping (Neuberg \& Newsom, 1993), and spontaneous trait inferences (Moskowitz, 1993). Preference for predictability refers to the need for consistency across circumstances and the aversion to change. Along with preference for order and structure, preference for predictability has been used to examine the personal need for structure by measuring the dislike of uncertainty and abrupt changes in plans (Moneta \& Yip, 2004). Discomfort with ambiguity is the need to have clarity in one's life and avoid confusion; this dimension is associated with ethnocentrism and prejudice (Block $\&$ Block, 1951) and high authoritarianism (Adorno et al., 1950). Closed-mindedness is the need to secure knowledge and avoid challenges to knowledge. Thórisdóttir and Jost (2011) indicated that the closed-mindedness correlates most weakly with the remaining four dimensions and rarely loads with them as a second-order latent factor (Mannetti et al., 2002; Neuberg et al., 1997). Because closed-mindedness items are quite general, relatively context free, and focused on motivation rather than skill per se, Thórisdóttir and Jost (2011) separated closed-mindedness from the other NFCC dimensions and demonstrated that it statistically mediated the relationship between threat and political conservatism. Decisiveness is the need to decide quickly and avoid indecision. Decisiveness-indica- 
ting an ability instead of the assumed motivational component, unlike the other facets of NFCC-has caused ambiguity in terms of the underlying dimensionality of NFCC (Roets \& Van Hiel, 2007). Leaptrott and McDonald (2008) used only the decisiveness dimension from NFCC and found that small business owners' decisiveness was positively related to their business performance.

Several views on NFCC dimensions have been put forth (Kruglanski \& Webster, 1996; Neuberg et al., 1997). Neuberg et al. (1997) indicated that inter-item homogeneity for the NFCC is weak; based on their confirmatory factor analysis, the NFCC is not a onedimensional instrument. They recommended using the NFCC as a two-factor instrument; such an approach is consistent with Kruglanski and Webster's (1996) two stage seizing-freezing process of cognitive closure. Furthermore, Lee et al. (2009) recently examined the relationship of each NFCC dimension and impulsive buying behavior. They did not include the preference for order and structure due to a measurement problem encountered in their pilot study. The results indicated that only three of the four NFCC components (i.e., decisiveness, discomfort with ambiguity, and closed-mindedness) influenced impulsive purchasing behavior. In light if the ongoing debate over the use of NFCC and previous studies using separate dimensions of NFCC, the current study uses all five dimensions of NFCC separately to investigate their effects on the perception of online reviews and behavior.

\section{Consumer Perception of Online Consumer Reviews}

\section{1) Attitudes}

Attitude is a person's general evaluation of other people, objects, and issues (Petty \& Cacioppo, 1984). Thus, one's attitude refers to how favorably or unfavorably one views some object of judgment or information. Attitude has been used as an important indicator of online consumer behavior. Several researchers have explored consumer attitudes toward online advertisements and found them to be effective in consumer responses such as attitudes toward product and websites (e.g., Korgaonkar \& Wolin, 2002; Wang et al., 2009). However, only a few researchers have studied consumer attitudes toward online consumer reviews (Doh \& Hwang, 2009; Lee \& Youn, 2009; Park \& Lee, 2008). Doh and Hwang (2009) explored consumers' evaluation of e-WOM and found that a few negative online reviews expressed positive attitudes toward both products and websites as the perfect sets with all positive messages can make consumers suspicious of e-WOM. Park and Lee (2008) studied general attitudes toward online reviews and found that, depending on the type of reviews and consumers' involvement, attitudes varied considerably.

With the exception of Park and Lee's (2008) study, previous studies have used online consumer reviews as an independent variable to measure attitudes toward product and websites. In Park and Lee's (2008) study, attitudes toward consumer reviews were used as a control variable to examine the effectiveness of consumer reviews. Thus, it would be worthwhile to examine attitudes toward consumer online reviews as a dependent variable to explore the effects of individual differences in consumer perceptions of online reviews.

\section{2) Influence of Online Reviews}

The information available for online shoppers is far more voluminous than the information available in stores (Bailey, 2005). According to Smith et al. (2005), many online consumers seek and accept recommendations from online consumer reviews to manage the amount of search information available. In contrast to traditional WOM, the impact of online consumer reviews can reach far beyond the local community as consumers all over the world can read an online review (Chen \& Xie, 2008). The spread of e-WOM communications and consumers' broad acceptance of it indicate that e-WOM can have a powerful effect on consumers' buying, information-gathering, and decisionmaking processes, ultimately increasing sales (Park \& Lee, 2009). As a result, online consumer reviews have become an important means of marketing communication and information source for consumers (Park \& Lee, 2009). Two roles that online consumer reviews 
play are as informants and recommenders (Park et al., 2007). As informants, online consumer reviews provide additional user-oriented product information; as recommenders, they either endorse a product or tell other consumers to avoid it (Park et al., 2007). Furthermore, previous studies have shown that the impact of online consumer reviews is dependent on product and consumer characteristics. Zhu and Zhang (2010) revealed that online reviews were more influential for less popular games and for games whose players have more Internet experience.

The influence of traditional WOM on consumer decision making has been tested empirically by measuring information seekers' perception of interpersonal communication (Gilly et al., 1998). Gilly et al. (1998) used a dyadic approach to design an active interpersonal information search model exploring the relationship between information seeker and source perceptions to measure WOM influence. Choi et al. (2008) examined whether different levels of NFCC affected the consumers' information search strategies (attribute-based search vs. alternative-based search), revealing that higher NFCC resulted in a greater preference for the attribute-based search than for the alternative-based search as well as the consideration of a smaller amount of information when making a final choice.

\section{3) Benefit of Online Reviews}

Online consumer reviews offer considerable benefits for consumers, including a large amount of available information, freedom from sales pressure, and 24-hour access to information sources beyond the local community (Prendergast et al., 2010). Compared to seller-generated product information, online consumer review is more likely to be relevant to consumers as it describes product attributes based on usage situations and product performance from a user's perspective (Chen \& Xie, 2008). Although more sophisticated consumers might find seller-generated product information more useful, novices can benefit from online consumer reviews that help them find products that they want. In addition, consumers can learn from product reviews written by others who have actually tried the product. Furthermore, online con- sumers can provide diagnostic value across multiple stages of the purchase decision process (Mudambi \& Schuff, 2010). Consumers can use online reviews not only to search for and assess alternatives, but also to post comments in the post-purchase evaluation stage to share opinions about their purchases (Mudambi \& Schuff, 2010).

\section{4) Persuasiveness of Online Review}

A major factor that influences consumers' perception of information's trustworthiness is the source's reason for providing the information (Prendergast et al., 2010; Romani, 2006). Product information posted by experienced users is likely to be trusted because the information providers are fellow consumers who likely have no interest in marketing the product (Prendergast et al., 2010). In addition, online consumer reviews have been proven to improve social presence of the websites and generate empathy (Galinsky et al., 2008; Kumar \& Benbasat, 2006). Furthermore, online consumer reviews help consumers decide whether to buy from or avoid an unfamiliar retailer (Chatterjee, 2001), especially when such reviews are confirmed by other consumers (Clare, 2010; Creamer, 2007; Goldsmith \& Horowitz, 2006). Therefore, sharing personal experiences online can cause the reader to empathize with the feelings of the writer, thereby enhancing persuasiveness (Deighton et al., 1989).

However, unlike traditional offline WOM, online reviews might not be fully informative if readers and reviewers have different preferences (Li et al., 2011). Previous studies on e-WOM have suggested that the persuasiveness of a message depends on the similarity between the source of the message and the recipients (Garbarino \& Strahilevitz, 2004; Kempf \& Palan, 2006). Li and Hitt's (2008) study demonstrated that unobservable preference differences between online reviewers and consumers using online reviews adversely affect consumers. They suggested that, because early buyers hold different preferences than later consumers do, online consumer reviews can be affected by purchase behaviors between early and later buyers. Chakravarty et al. (2010) studied the effects of online consumer and professional reviews on consumer product evaluations, finding that infrequent 
consumers are more influenced by online consumer reviews than frequent consumers are whereas frequent consumers are more influenced by professional reviews.

Klein and Webster (2000) examined whether individuals perceive persuasive messages according to their level of NFCC; they determined that low NFCC individuals are persuaded by strong arguments rather than by heuristic cues while high NFCC individuals are just the opposite. As indicated by previous studies, depending on their characteristics, consumers could be influenced in different ways by online consumer reviews.

\section{Age and Gender}

Age and gender are variables that capture many socioeconomic as well as various individual characteristics when studying online consumer behaviors (e.g., Bae \& Lee, 2011; Djamasbi et al., 2011; Ono \& Zavodny, 2003; Sun \& Wang, 2010). Earlier studies identified a significant gender gap in consumers' use of the Internet and online shopping. Females tend to invest less effort and time on the Internet, perceive online shopping as riskier, and be influenced by online consumer reviews (Bae \& Lee, 2011; Ono \& Zavodny, 2003). Other studies have found that male and female customers process online information differently: Females are relational processors who focus on all available information, are sensitive to the details of messages, and process information in a comprehensive and effortful way (Meyers-Levy, 1989; Putrevu, 2001) while male consumers tend to focus on only the information that they think is useful and that fits into a preexisting schema (Meyers-Levy, 1989; Putrevu, 2001).

Although few studies have explored age differences in online consumer reviews, social value studies have shown that different age groups might have different value systems. Each generation ascribes certain values to the societal, political, and historical events of their formative years (Sun \& Wang, 2010). As such, according to Djamasbi et al. (2011), generations such as generation $Y$ have a different sense of immediacy, a shorter attention span, and less patience than older generations, resulting in different web page vie- wing behavior and online information processing. In addition, older generations are more willing to expend their cognitive effort than younger generations when viewing web pages. Previous studies have also shown that younger generations seem to have more web experience and tend to be more web-literate than older generations (Dennis et al., 2002), which instills positive attitudes toward online shopping (Dillon \& Reif, 2004). Cole et al. (2008) found that age-associated changes in consumer cognition, affect, and goals cause older adults' decision-making process, brand choices, and habits to differ from those of younger adults. Therefore, in this study, we looked at both gender and age as independent variables to examine how individual differences in NFCC influenced consumer perception and usage of consumer reviews during online shopping.

\section{Consumer Review Usage Behavior}

The importance of studying online consumer reviews is evidenced by the way in which consumers use them. According to a recent survey by Brand Reputation, $84 \%$ of consumers said they were more likely to check online for a review prior to making a purchase (The Retail Bulletin, 2009). A survey conducted by 2010 Consumer Shopping Habits indicated that $92 \%$ of those surveyed said they read product reviews when considering purchasing a product; of these, $46 \%$ have been influenced by online consumer reviews when thinking about purchasing a product and $43 \%$ have not made a purchase after reading negative reviews. Another 57\% returned the favor by leaving reviews on websites after their purchase for future buyers ("Through the eyes", 2010).

Consumers' use of online reviews can reveal their purchase intention. Previous studies have shown close relationships between frequent Internet shopping and perceived usefulness of online reviews as well as frequency of online consumer review usage and positive online shopping behavior. Park and Lee (2009) found that Internet shopping has a significant effect on the perceived usefulness of online reviews and that positive attitudes toward online reviews lead to more frequent use of online reviews. Senecal and Nantel 
(2004) demonstrated that their study participants who consulted product recommendations selected recommended products twice as often as consumers who did not, with some inconsistencies across recommendation source and product category. Therefore, it is imperative to examine how different levels of NFCC can affect the use of online consumer reviews.

Given the previous NFCC-related literature, consumers' perception of online reviews and usage behaviors as well as age- and gender-related effects on online consumer reviews, the following research questions were developed for the current study:

How does each dimension of NFCC affect consumers' perception of online reviews (i.e., attitudes, online review influence, benefits, and persuasiveness from online reviews)?

How does each dimension of NFCC affect online review usage behaviors?

How do individual demographic variables (i.e., gender, age) affect consumers' perception of online reviews (i.e., attitudes, online review influence, benefits, and persuasiveness from online reviews)?

How do individual demographic variables (i.e., gender, age) impact consumers' online review usage behaviors?

\section{Methods}

\section{Sampling and Procedure}

A marketing research company was used to identify nationwide American online shoppers who are 18 years old or older. Using random sampling, participants were recruited nationally. Only consumers who had already shopped from various online retailers such as Amazon.com, Apple.com, BestBuy.com, CDW.com, Dell.com, eBay.com, HP.com, JCPenney.com, NewEgg.com, OfficeDepot.com, Overstock.com, Sears.com, Staples.com, Target.com, ToysRUS.com, Walmart.com, and Yahoo.com and had consulted online reviews for their purchase decision-making process were included in the study. Screening questions were used to identify participants who met these criteria. Data were collected through an online survey. Dillman's (2000) online survey procedures, including initial invitation e-mail with two reminder e-mails, were used.

\section{Instrument}

NFCC was assessed through 24 multi-item scales developed by Kruglanski and Webster (1996). Attitudes toward online consumer reviews were assessed on a seven-point bipolar scale, using four items from Huff and Alden (1998). In addition, four items were adopted from Gilly et al. (1998) to capture the influence of consumer reviews. To measure the perceived benefit of consumers' reviews, four items from Gwinner et al. (1998) were used. Persuasiveness of consumer reviews was assessed using four items from Reichert et al.'s (2001) study. Three items from Park and Lee's (2009) study were used to assess frequent usage behavior of consumer reviews. The items used in the current study were modified for the context of consumer reviews from the original scales. All items except attitudes toward online consumer reviews were measured on a seven-point Likert scale ( 1 = strongly disagree, 7 = strongly agree). Participants were also asked to respond to demographics questions. A descriptive analysis, $t$-test, exploratory factor analysis, and regressions analysis were conducted to analyze the data using SPSS 19.0.

\section{Results and Discussion}

\section{Non-response Bias}

Based on the assumption that participants who responded late are often assumed to be similar to nonrespondents (Armstrong \& Overton, 1977), 10\% of the early and late responses were compared for the research variables and demographics used in the study. The insignificant results of the $t$-tests between the two group $(p>.1)$ indicated no suspicion of nonresponse bias.

\section{Sample Characteristics}

A total of 2,664 survey responses were collected, yielding a response rate of $13.3 \%$, of which 2,381 complete responses were deemed usable for data analysis. Approximately $53.0 \%$ of the respondents were 
female, and the majority of the respondents were European American (83.0\%), followed by African American (7.5\%), Hispanic American (6.6\%), Asian American $(3.9 \%)$, and Native Hawaiian or Pacific Islander (2.2\%). More than three quarters of the participants had at least some college education (77.1\%). Almost half of the respondents $(48.0 \%)$ were married and employed (54.1\%). Respondents represented all income categories: less than $\$ 24,999(25.3 \%), \$ 25,000$ to 49,999 (51.3\%), $\$ 50,000$ to $\$ 74,999(11.3 \%)$, and $\$ 75,000$ or more $(12 \%)$.

\section{Preliminary Data Analysis}

To test construct validity, a principal component analysis using varimax rotation was conducted for the multi-item research variables (Table 1). Factor loadings above .55 (Nunnally \& Bernstein, 1994) and not higher than .30 on other factors (Kline, 2007) are considered evidence of construct validity. Internal consistency was examined next using the Cronbach's alpha value, with an acceptable level of at least .70 (Peterson, 1994). However, an alpha above .60 can be satisfactory evidence in multi-item measure (Bagozzie \& Yi, 1988; Hair et al., 1998). All the research variables with the exception of NFCC had a single dimension with factor loadings from .83 to .95 ; alpha values were acceptable, ranging from .89 to .93 . As shown in Table 1, the results revealed the five dimensions of NFCC, consistent with previous studies (Kruglanski \& Webster, 1996; Mannetti et al., 2002; Roets $\&$ Van Hiel, 2007). Factor loadings ranged from .65

Table 1. Results of EFA and reliability for NFCC

\begin{tabular}{|c|c|c|c|c|}
\hline Dimensions / Items & $\begin{array}{l}\text { Factor } \\
\text { loading }\end{array}$ & Eigenvalues & $\begin{array}{c}\% \text { of variance } \\
\text { explained }\end{array}$ & alpha \\
\hline \multicolumn{5}{|l|}{ Preference for order and structure } \\
\hline $\begin{array}{l}\text { I find that a well ordered life with a regular house suits my temperament. } \\
\text { I believe that orderliness and organization are among the most important charac- } \\
\text { teristic of a good student. } \\
\text { I find that establishing a consistent routine enables me to enjoy life more. } \\
\text { I enjoy having a clear and structured mode of life. }\end{array}$ & $\begin{array}{l}.74 \\
.77 \\
.85 \\
.84\end{array}$ & 4.88 & $28.68 \%$ & .85 \\
\hline \multicolumn{5}{|l|}{ Preference for predictability } \\
\hline $\begin{array}{l}\text { I enjoy the uncertainty of going into a new situation without knowing what might } \\
\text { happen (R). } \\
\text { I dislike unpredictable situations. } \\
\text { I don't like to go into a situation without knowing what I can expect from it. }\end{array}$ & $\begin{array}{l}.72 \\
.77 \\
.76\end{array}$ & 2.54 & $14.93 \%$ & .68 \\
\hline \multicolumn{5}{|l|}{ Discomfort with ambiguity } \\
\hline $\begin{array}{l}\text { I dislike it when personal statements could mean many different things. } \\
\text { It is annoying to listen to someone who cannot make up their mind. } \\
\text { I feel uncomfortable when someone's meaning or intention is unclear. }\end{array}$ & $\begin{array}{l}.78 \\
.80 \\
.78\end{array}$ & 2.07 & $12.18 \%$ & .88 \\
\hline \multicolumn{5}{|l|}{ Closed-mindedness } \\
\hline $\begin{array}{l}\text { Even after I have made up my mind about something I am always eager to consi- } \\
\text { der a different opinion (R). } \\
\text { When considering most conflict situation, I can usually see how both sides could } \\
\text { be right (R). } \\
\text { When thinking about a problem, I consider as many different opinions on the issue } \\
\text { as possible (R). } \\
\text { I always see many different solutions to problems I face (R). }\end{array}$ & $\begin{array}{l}.65 \\
.80 \\
.82 \\
.78\end{array}$ & 1.49 & $8.74 \%$ & .77 \\
\hline \multicolumn{5}{|l|}{ Decisiveness } \\
\hline $\begin{array}{l}\text { I would describe myself as indecisive (R). } \\
\text { I tend to struggle with most decisions (R). } \\
\text { When trying to solve a problem I often see so many possible options that it is con- } \\
\text { fusing }(\mathrm{R}) \text {. }\end{array}$ & $\begin{array}{l}.90 \\
.92 \\
.84\end{array}$ & 1.12 & $6.57 \%$ & .79 \\
\hline Total variance explained & & & $71.10 \%$ & \\
\hline
\end{tabular}

Items with (R) were reversely coded 
to .92 , and alpha values from .68 to .88 . Overall, 17 of the 24 original items remained, explaining $71.1 \%$ of the total variance. Thus, the research construct in the present study met all the criteria for showing good validity and reliability.

\section{Effects of NFCC, Gender, and Age on Con- sumers' Perceptions and Review Usage Be- haviors}

A series of multiple regression analyses were performed using consumers' perception variables, such as attitudes, online review influence, benefit, and persuasiveness, as well as consumers' reviews usage behaviors as dependent variables and the five NFCC dimensions as independent variables. To explore the influence of respondents' gender and age, these two variables were also analyzed as independent variables. For gender, a dummy code (male $=0$, female $=1$ ) was created and added to the regression analyses. There was no evidence of multicollinearity among the independent variables in the regression models.

The results $<$ Table $2>$ indicate that preference for order and structure $(\beta=.15, p<.001)$, discomfort with ambiguity $(\beta=.09, p<.001)$, closed-mindedness $(\beta=$ $-.23, p<.001)$, decisiveness $(\beta=.10, p<.001)$, and gen$\operatorname{der}(\beta=.09, p<.001)$ significantly influence attitudes toward online consumer reviews, with $R^{2}$ being .14 , whereas preference for predictability and age did not show such an influence at the level of $p<.05$. In terms of consumers' perceived influence of online consumer reviews, preference for order and structure $(\beta=$ $.16, p<.001)$, discomfort with ambiguity $(\beta=.16, p<$ $.001)$, closed-mindedness $(\beta=-.33, p<.001)$, and gen$\operatorname{der}(\beta=.09, p<.001)$ showed a significant effect, with $R^{2}$ being .26 , whereas preference for predictability, decisiveness, and age did not at the $p<.05$ level. Similarly, preference for order and structure $(\beta=.15, p<$ $.001)$, discomfort with ambiguity $(\beta=.13, p<.001)$, closed-mindedness $(\beta=-.27, p<.001)$, age $(\beta=-.01, p<$ $.001)$, and gender $(\beta=.06, p<.01)$ had a significant effect on perceived benefits, with $R^{2}$ being .14; preference for predictability and decisiveness did not show such an influence at the $p<.05$ level. A similar pattern was found for persuasiveness of online consumer re- views; preference for order and structure $(\beta=.14, p<$ $.001)$, discomfort with ambiguity $(\beta=.13, p<.001)$, closed-mindedness $(\beta=-.29, p<.001)$, age $(\beta=-.06, p<$ $.01)$, and gender $(\beta=.04, p<.05)$ showed significant influence, with $R^{2}$ being .20 , whereas preference for predictability and decisiveness did not demonstrate such an influence at the $p<.05$ level. Finally, consumers' usage behavior with online consumer reviews was predicted by preference for order and structure $(\beta=$ $.11, p<.001)$, discomfort with ambiguity $(\beta=.08, p<$ $.001)$, closed-mindedness $(\beta=-.25, p<.001)$, decisiveness $(\beta=.05, p<.05)$, and age $(\beta=-.14, p<.001)$, with $R^{2}$ being 12 .

The results indicated that consumers who prefer order and structure, clarity, and challenges to knowledge, but avoid indecision are likely to have favorable attitudes toward online consumer reviews and tend to use them regularly. Furthermore, consumers who prefer order and structure, clarity, and challenges to knowledge are likely to perceive positive or greater online review influence, benefits, and persuasiveness from online consumer reviews. Those who are younger tend to feel more benefits and persuasiveness, and use online consumer reviews more frequently. Female consumers are more likely to have a positive perception of online reviews (i.e., in terms of attitudes, online review influence, benefits, and persuasiveness from online reviews). However, no significant gender difference emerged in the review usage behavior. Interestingly, consumers' preference for predictability did not influence any attitudes, online review influence, benefits, persuasiveness, or usage behaviors.

\section{Discussion and Conclusions}

Online consumer reviews have become one of the most trusted forms of advertising and a major informational source for consumers' decision making (Chatterjee, 2001; Mudambi \& Schuff, 2010); as such, it is critical to understand consumers' different perceptions based on individual characteristics of the online consumer reviews (Lee \& Ma, 2012). This study empirically investigated the effects of NFCC and demographic characteristics as an individual difference on 
Table 2. Results of multiple regression analysis

\begin{tabular}{|c|c|c|c|c|}
\hline Dependent variables & Independent variables & $\beta$ (Standardized Beta) & Adj. $R^{2}$ & $\overline{F F}$ \\
\hline Attitudes & $\begin{array}{r}\text { Preference for order and structure } \\
\text { Preference for predictability } \\
\text { Discomfort with ambiguity } \\
\text { Closed-mindedness } \\
\text { Decisiveness } \\
\text { Age } \\
\text { Male }(=0) / \text { Female }(=1)\end{array}$ & $\begin{array}{l}.15^{* * *} \\
.00 \\
.09^{* * *} \\
-.23 * * * \\
.10^{* * *} \\
-.01 \\
.09 * * *\end{array}$ & .14 & $54.15 * * *$ \\
\hline $\begin{array}{l}\text { Online Review } \\
\text { Influence }\end{array}$ & $\begin{array}{r}\text { Preference for order and structure } \\
\text { Preference for predictability } \\
\text { Discomfort with ambiguity } \\
\text { Closed-mindedness } \\
\text { Decisiveness } \\
\text { Age } \\
\text { Male }(=0) / \text { Female }(=1)\end{array}$ & $\begin{array}{l}.16^{* * *} \\
.03 \\
.16^{* * *} \\
-.33^{* * *} \\
.03 \\
-.02 \\
.09 * * *\end{array}$ & .26 & $119.08 * * *$ \\
\hline Benefit & $\begin{array}{r}\text { Preference for order and structure } \\
\text { Preference for predictability } \\
\text { Discomfort with ambiguity } \\
\text { Closed-mindedness } \\
\text { Decisiveness } \\
\text { Age } \\
\text { Male }(=0) / \text { Female }(=1)\end{array}$ & $\begin{array}{l}.15^{* * *} \\
.03 \\
.13^{* * *} \\
-.27^{* * *} \\
.04 \\
-.07^{* * *} \\
.06^{* *}\end{array}$ & .19 & $78.32 * * *$ \\
\hline Persuasiveness & $\begin{array}{r}\text { Preference for order and structure } \\
\text { Preference for predictability } \\
\text { Discomfort with ambiguity } \\
\text { Closed-mindedness } \\
\text { Decisiveness } \\
\text { Age } \\
\text { Male }(=0) / \text { Female }(=1)\end{array}$ & $\begin{array}{l}.14 * * * \\
.02 \\
.13 * * * \\
-.29 * * * \\
-.02 \\
-.06 * * \\
.04 *\end{array}$ & .20 & $83.86 * * *$ \\
\hline $\begin{array}{l}\text { Consumer Reviews } \\
\text { Usage Behavior }\end{array}$ & $\begin{array}{r}\text { Preference for order and structure } \\
\text { Preference for predictability } \\
\text { Discomfort with ambiguity } \\
\text { Closed-mindedness } \\
\text { Decisiveness } \\
\text { Age } \\
\text { Male }(=0) / \text { Female }(=1)\end{array}$ & $\begin{array}{l}.11^{* * *} \\
-.02 \\
.08^{* * *} \\
-.25^{* * *} \\
.05^{*} \\
-.11^{* * *} \\
.00\end{array}$ & .12 & $46.70 * * *$ \\
\hline
\end{tabular}

${ }^{*} p<.05,{ }^{* *} p<.01,{ }^{* * *} p<.001$

consumer perception and usage behavior with regard to online consumer reviews. NFCC appears to have value for analyzing consumers' decision processing, such as consumer choice process and buying behavior (Houghton \& Grewal, 2000; Lee et al., 2009). The need exists to clarify NFCC dimensions in consumer behavior research as previous studies have addressed different views on NFCC dimensions (Kruglanski \& Webster, 1996; Neuberg et al., 1997) and issues with certain elements of NFCC (Leaptrott \& McDonald, 2008; Mannetti et al., 2002; Neuberg et al., 1997; Roets \& Van Hiel, 2007; Thórisdóttir \& Jost, 2011). Thus, the present study examined the specific effect of individual dimensions of NFCC on online consumer re- views and demonstrated the different influence of those dimensions on online review perceptions as well as frequent usage behaviors. This study contributes to the body of literature on NFCC by confirming that five dimensions of NFCC can be examined separately, as each component can have a different effect on consumers' responses.

The findings of this study revealed that preference for order and structure and discomfort with ambiguity had positive influences on all consumers' perception and behavior variables. As online reviews can be used to reduce consumers' uncertainty by confirming their purchase decisions with peer-generated comments about product or services (Berger \& Calabrese, 
1975; Bradac, 2001; Brumfield, 2008; Hogg, 2000; Hu et al., 2008), consumers who try to have clarity and avoid uncertainty (Vermeir \& Van Kenhove, 2005; Webster \& Kruglanski, 1994) were likely to perceive positive perceptions toward online reviews as well as show frequent use of online reviews. In addition, this study identified the negative effects of closed-mindedness on consumers' perceptions and usage behavior related to online reviews as opposed to other dimensions. Sometimes online consumer reviews provide dense information that could cause information overload (Park \& Lee, 2008); consumers with a high tendency of closed-mindedness would prefer to avoid challenges to their knowledge stemming from such overwhelming information. Furthermore, this result was consistent with other studies indicating that closed-mindedness behaves differently from other NFCC dimensions (Mannetti et al., 2002; Neuberg et al., 1997; Thórisdóttir \& Jost, 2011).

The results of the study did not show significant effects of preference for predictability on any of perceptions and behavior variables. Insignificant effects of preference for predictability on all the variables in the present study can be explained by the characteristic of its dimension and online review context. Consumers with a high preference for predictability prefer consistency across circumstances. However, sometimes consumers face conflicting information about a product, service, or company, which can hinder their information processing and increase difficulty in their decision making (Ghose \& Ipeirotis, 2007; Yao et al., 2009).

The dimension of decisiveness had a positive effect on attitudes and usage behaviors associated with online consumer reviews, whereas it did not indicate an impact on online review influence, perceived benefits, and persuasiveness. Those who have a high tendency of avoiding indecision seem to be more likely to take advantage of online consumer reviews. However, reviewing numerous consumer posts online takes time; moreover, mixed opinions on reviews might delay a decision. In this sense, consumers who resist indecision might not perceive enough influence on their decision, benefits, or persuasiveness from online consumer reviews. Previous studies have also argued that decisiveness constitutes an independent and distinctive dimension, but its construct validity can be questionable in terms of being a part of NFCC (Mannetti et al., 2002; Neuberg et al., 1997). Most items in the NFCC scale refer to motivation and preferences of closure, but decisiveness scale measures the perceived ability rather than a motivational component (Roets \& Van Hiel, 2007). Therefore, the unclear nature of the decisiveness scale might explain the results of our study.

Age and gender were also examined to determine whether they had a significant impact on consumers' perceptions and behavior variables. Young consumers were found to be more likely to perceive positive or greater benefits and persuasiveness of online reviews and demonstrate more frequent usage behaviors, confirming the previous literature (Cole et al., 2008; Dillon \& Reif, 2004; Putrevu, 2001) and emphasizing that younger consumers have positive attitudes toward online experience and are more likely to shop online. Females had more positive perceptions of online reviews with the exception of behavior; such results support the findings from Bae and Lee's (2011) study. Therefore, the present study has important implications for future research on the age and gender gaps in online shopping, especially different consumers' perceptions toward online consumer reviews and usage behavior due to individual age and gender differences.

Our research offers some practical implications for online retailers to consider in terms of individual differences. For example, to appeal to a variety of consumers with different levels of NFCC, online retailers can offer guidelines or hints to online reviewers about how to write a review, which would promote more persuasive and efficient reviews for certain types of products or target markets. For apparel retailers in particular, it would be helpful to establish a more systematic online review process so that consumers can read detailed information about apparel products from other peer shoppers, including information related to size, color, and material. For online retailers who target younger consumer cohorts, it would be beneficial to provide favorable opportunities for them to post and read consumers' comments. For instance, using 
social media such as Twitter, Facebook, blogs, and YouTube might appeal to younger consumers. In addition, the positive perception of female and younger consumers' online reviews could be especially be helpful for fashion or apparel online retailers in terms of product promotion, as both female and collegeaged consumers are highly involved in online communities and apparel is one of the most popular online shopping categories for them (Case \& King, 2003; Park \& Cho, 2012). To our knowledge, no previous studies have examined apparel online shoppers in relation to their cognitive information process of online reviews. Although this study did not focus exclusively on online apparel consumers, by exploring other various online consumers' online review information process, the findings of this study provide important insights for online apparel retailers utilizing online consumer reviews. For example, our results indicated that one component of NFCC, closedmindedness, had significant negative effects on all three online perceptions (i.e., attitudes, benefits, and persuasiveness). Unlike offline settings, where consumers can interact with salespersons or peers and ask opinions about their apparel choice, online apparel shoppers who are low in closed-mindedness can benefit from online consumer reviews during their decision-making process. Therefore, apparel retailers need to consider promoting online reviews and setting up more organized online review tools for apparel consumers so they can access different opinions from others about various aspects of the product during their online apparel shopping.

Consumers' cognitive process in the informationgathering and decision-making stages can also be influenced by other situational variables, such as time constraints, as indicated by previous NFCC studies (Kruglanski \& Freund, 1983; Shah et al., 1998). However, the present study did not examine other variables that might influence NFCC in the online review context. Thus, it would be meaningful to examine the effect of NFCC in the online review context while considering situational variables that might impact consumers' decision-making process. In addition, consumers' cognitive process might vary by product categories in online review usage; this study was con- ducted with a variety of product categories, not with any particular product categories. Thus, future studies should investigate the influence of NFCC on online consumers' reviews for specific product categories, such as fashion or apparel, to identify differences. Because of the ongoing debate on the dimensionality of NFCC, further research is needed to reevaluate the structure of NFCC and explore other ways of constructing NFCC scales for a better understanding of cognitive process of consumer behavior.

\section{References}

Adorno, T. W., Frenkel-Brunswik, E., Levinson D. J., \& Sanford, R. N. (1950). The authoritarian personality. New York: Harper \& Row.

Armstrong, S. J., \& Overton, T. S. (1977). Estimation nonresponse bias in mail surveys. Journal of Marketing Research, 14(3), 396-402.

Bae, S., \& Lee, T. (2011). Gender differences in consumers' perception of online consumer reviews. Electronic Commerce Research, 11(2), 201-214.

Bagozzie, R. P., \& Yi, Y. (1988). On the evaluation of structural equation models. Journal of the Academy of Marketing Science, 16(1), 74-94.

Bailey, A. A. (2005). Consumer awareness and use of product review websites. Journal of Interactive Advertising, $6(1), 68-81$.

Berger, C. R., \& Calabrese, R. J. (1975). Some explorations in initial interaction and beyond: Toward a developmental theory of interpersonal communication. Human Communication Research, 1(2), 99-112.

Bettman, J. R. (1973). Perceived risk and its components: A model and empirical test. Journal of Marketing Research, 10(2), 184-190.

Bickart, B., \& Schindler, R. M. (2001). Internet forums as influential sources of consumer information. Journal of Interactive Marketing, 15(3), 31-40.

Block, J., \& Block, J. (1951). An investigation of the relationship between intolerance of ambiguity and ethnocentrism, Journal of Personality, 19(3), 303-311.

Bradac, J. J. (2001). Theory comparison: Uncertainty reduction, problematic integration, uncertainty management, and other curious constructs. Journal of Communication, 51(3), 456-476.

Brumfield, E. J. (2008). Using online tutorials to reduce uncertainty in information seeking behavior. Journal of Library Administration, 48(3-4), 365-377.

Case, C. J., \& King, D. L. (2003). Quantifying student internet purchasing behavior. In A. Alkafaj \& J. Bivermen (Eds.), Business research yearbook, 10 (pp. 88-92). Sa- 
line, MI: Mcmaughton \& Gunn.

Chakravarty, A., Liu, Y., \& Mazumdar, T. (2010). The differential effects of online word-of-mouth and critics' reviews on pre-release movie evaluation. Journal of Interactive Marketing, 24(3), 185-197.

Chatterjee, P. (2001). Online reviews: Do consumers use them? In M. C. Gilly \& J. Myers-Levy (Eds.), Advances in consumer research (pp. 129-134). Provo, UT: Association for Consumer Research.

Chen, Y., \& Xie, J. (2008). Online consumer review: Wordof-mouth as a new element of making communication mix. Management Science, 54(3), 477-491.

Choi, J. A., Koo, M., Choi, I., \& Auh, S. (2008). Need for cognitive closure and information search strategy. Psychology \& Marketing, 25(11), 1027-1042.

Clare, C. (2010). Receiver perspectives of the determinants that influence eWOM adoption: An exploratory study. MMU Research, Research Institute for Business and Management. Retrieved March 10, 2010, from http:// www.ribm.mmu.ac.uk/symposium2010/fullpapers/Clare, $\% 20$ Carl.pdf

Cole, C., Laurent, G., Drolet, A., Ebert, J., Gutchess, A., Lambert-Pandraud, R., Mullet, E., Norton, M., \& Peters, E. (2008). Decision making and brand choice by older consumers. Marketing Letters, 19(3-4), 355-365.

Creamer, M. (2007). At last, the reviews are in: Wal-Mart wakes up to the power of the people. Advertising Age, 78(29), 1-27. Retrieved September 14, 2009, from http:// adage.com/article?article_id $=119456$

Deighton, J., Romer, D., \& McQueen, J. (1989). Using drama to persuade. Journal of Consumer Research, 16(3), 335343.

Dennis, C., Harris, L., \& Sandhu, B. (2002). From bricks to clicks: Understanding the e-consumer. Qualitative Marketing Research, 5(4), 281-290.

Dillman, D. A. (2000). Mail and Internet surveys: The tailored design method. New York: John Wiley \& Sons.

Dillon, T., \& Reif, H. (2004). Factors influencing consumers' e-commerce commodity purchases. Information Technology Learning, and Performance Journal, 22(2), $1-12$.

Djamasbi, S., Siegel, M., Skorinko, J., \& Tullis, T. (2011). Online viewing and aesthetic preferences of generation $\mathrm{Y}$ and the baby boom generation: Testing user Web site experience through eye tracking. International Journal of Electronic Commerce, 15(4), 121-158.

Doh, S. J., \& Hwang, J. S. (2009). How consumers evaluate eWOM (electronic word of-mouth) messages. Cyberpsychology \& Behavior, 12(2), 193-197.

Galinsky, A. D., Maddux, W. W., Gilin, D., \& White, J. B. (2008). Why it pays to get inside the head of your opponent: The differential effects of perspective taking and empathy in negotiations. Psychological Science, 19(4),
$378-384$.

Garbarino, E., \& Strahilevitz, M. (2004). Gender differences in the perceived risk of buying online and the effects of receiving a site recommendation. Journal of Business Research, 57(7), 768-775.

Ghose, A., \& Ipeirotis, P. G. (2007). Designing novel review ranking systems: Predicting the usefulness and impact of reviews. Proceedings of the ninth international conference on Electronic Commerce, USA, 303-309.

Gilly, M. C., Graham, J. L., Wolfinbarger, M. F., \& Yale, L. J. (1998). A dyadic study of interpersonal information search. Journal of Academy of Marketing Science, 26(2), 83-100.

Global advertising: Consumers trust real friends and virtual strangers the most. (2009, July 7). Nielsen Company. Retrieved January 29, 2012, from http://blog.nielsen. com/nielsenwire/consumer/global-advertising-consumers-trust-real-friends-and-virtual-strangers-the-most/

Goldsmith, R. E., \& Horowitz, D. (2006). Measuring motivations for online opinion seeking. Journal of Interactive Advertising, 6(2), 3-14.

Gruen, T. W., Osmonbekov, T., \& Czaplewski, A. J. (2006). e-WOM: The impact of customer-to-customer online know-how exchange on customer value and loyalty. Journal of Business Research, 59(4), 449-456.

Gwinner, K. P., Gremler, D. D., \& Bitner, M. J. (1998). Relational benefits in services industries: The customer's perspective. Journal of the Academy of Marketing Science, 26(2), 101-114.

Hair, J. F., Anderson, R. E., Tatham, R. L., \& Black, W. C. (1998). Multivariate data analysis $\left(5^{\text {th }}\right.$ ed.). Upper Saddle River, NJ: Prentice Hall.

Hennig-Thurau, T., Gwinner, K. P., Walsh, G., \& Gremler, D. D. (2004). Electronic word-of-mouth via consumeropinion platforms: What motivates consumers to articulate themselves on the Internet? Journal of Interactive Marketing, 18(1), 38-52.

Hogg, M. A. (2000). Subjective uncertainty reduction through self-categorization: A motivational theory of social identity processes. European Review of Social Psychology, 11(1), 223-255.

Houghton, D. C., \& Grewal, R. (2000). Please, let's get an answer - any answer: Need for consumer cognitive closure. Psychology \& Marketing, 17(11), 911-934.

Hu, N., Liu, L., \& Zhang, J. J. (2008). Do online reviews affect product sales? The role of reviewer characteristics and temporal effects. Information Technology and Management, 9(3), 201-214.

Huff, L. C., \& Alden, D. L. (1998). An investigation of consumer response to sales promotions in developing markets: A three-country analysis. Journal of Advertising Research, 38(3), 47-56.

Kempf, D. A. S., \& Palan, K. M. (2006). The effects of gen- 
der and argument strength on the processing of wordof-mouth communication. Academy of Marketing Studies Journal, 10(1), 1-18.

Klein, C. T. F., \& Webster, D. M. (2000). Individual differences in argument scrutiny as motivated by need for cognitive closure. Basic and Applied Social Psychology, 22(2), 119-129.

Kline, R. B. (2007). Principles and practices of structural equation modeling $\left(2^{\text {nd }}\right.$ ed.). New York, NY: The Guilford Press.

Korgaonkar, P., \& Wolin, L. D. (2002). Web usage, advertising, and shopping: Relationship patterns. Internet Research: Electronic Networking Applications and Policy, 12(2), 191-204.

Kotler, P., \& Keller, K. L. (2005). Marketing management $\left(12^{\text {th }}\right.$ ed.). Upper Saddle River, NJ: Pearson PrenticeHall.

Kruglanski, A. W., \& Webster, D. M. (1994). Motivated closing of the mind: "Seizing" and "freezing." Psychological Review, 103(2), 263-283.

Kruglanski, A. W., \& Freund, T. (1983). The freezing and unfreezing of lay-inferences: Effects of impressional primacy, ethnic stereotyping, and numerical anchoring. Journal of Experimental Social Psychology, 19(5), 448-468.

Kruglanski, A. W., Webster, D. M., \& Klem, A. (1993). Motivated resistance and openness to persuasion in the presence or absence of prior information. Journal of Personality and Social Psychology, 65(5), 861-876.

Kruglanski, A. W., Atash, M. N., De Grada, E., Mannetti, L., Pierro, A., \& Webster, D. M. (1997). Psychological theory testing versus psychometric nay-saying: Comment on Neuberg et al.'s (1997) critique of the need for closure scale. Journal of Personality and Social Psychology, 73(5), 1005-1016.

Kumar, N., \& Benbasat, I. (2006). Research note: The influence of recommendations and consumer reviews on evaluations of websites. Information Systems Research, 17(4), 425-439.

Lau, G. F., \& Ng, S. (2001). Individual and situational factors influencing negative word of-mouth behaviour. Canadian Journal of Administrative Sciences, 18(3), 163-178.

Leaptrott, J., \& McDonald, J. M. (2008). Looking before leaping: The effect of owner decisiveness on small business performance. Academy of Entrepreneurship Journal, 14(1), 1-12.

Lee, H. H. (2012). Attributes of online review systems: An environmental design perspective. Journal of Global Fashion Marketing, 3(4), 158-171.

Lee, H. H., \& Ma, Y. J. (2012). Consumer perceptions of online consumer product and service reviews: Focusing on information processing confidence and susceptibility to peer influence. Journal of Research in Interactive Marketing, 6(2), 110-132.
Lee, M. H., Schellhase, R., Koo, D. M., \& Lee, M. J. (2009). The impacts of need for cognitive closure, psychological wellbeing, and social factors on impulse purchasing. Journal of Global Academy of Marketing Science, 19(4), 44-56.

Lee, M., \& Youn, S. (2009). Electronic word of mouth: How eWOM platforms influence consumer product judgment. International Journal of Advertising, 28(3), 473499.

Li, X., \& Hitt, L. M. (2008). Self-selection and information role of online product reviews. Information Systems Research, 19(4), 456-474.

Li, X., Hitt, L. M., \& Zhang, Z. J. (2011). Product reviews and competition in markets for repeat purchase products. Journal of Management Information Systems, 27 (4), 9-42.

Mannetti, L., Pierro, A., Kruglanski, A., Taris, T., \& Bezinovic, P. (2002). A cross-cultural study of the need for cognitive closure scale: Comparing its structure in Croatia, Italy, USA and the Netherlands. British Journal of Social Psychology, 41(1), 139-156.

Meyers-Levy, J. (1989). Gender differences in information processing: A selectivity interpretation. In. P. Caferrata $\&$ A. Tybout (Eds.), Cognitive and affective responses to advertising (pp. 219-260). Lexington, MA: Lexington Books.

Moneta, G. B., \& Yip, P. P. Y. (2004). Construct validity of the scores of the Chinese version of the need for closure scale. Educational and Psychological Measurement, 64(3), 531-548.

Moskowitz, G. B. (1993). Individual differences in social categorization: The influence of personal need for structure on spontaneous trait inferences. Journal of Personality and Social Psychology, 65(1), 132-142.

Mudambi, S. M., \& Schuff, D. (2010). What makes a helpful online review? A study of customer reviews on Amazon.com. MIS Quarterly, 34(1), 185-200.

Neuberg, S. L., \& Newsom, J. T. (1993). Personal need for structure: Individual differences in the desire for simpler structure. Journal of Personality and Social Psychology, 65(1), 113-131.

Neuberg, S. L., Judice, T. N., \& West, S. G. (1997). What the need for closure scale measures and what it does not: Toward differentiating among related epistemic motives. Journal of Personality and Social Psychology, 72(6), 1396-1412.

Nunnally, J. C., \& Bernstein, I. H. (1994). Psychometric theory $\left(3^{\text {rd }}\right.$ ed.). New York, NY: McGraw-Hill.

Online consumer-generated reviews have significant impact on offline purchase behavior. (2007, November 29). com Score. Retrieved February 1, 2012, from www.comscore. com/Press_Events/Press_Releases/2007/11/Online_Consumer_Reviews_Impact_Offline_Purchasing_Behavior/ 
Ono, H., \& Zavodny, M (2003). Gender and the Internet. Social Science Quarterly, 84(1), 111-121.

Park, C., \& Lee, T. M. (2009). Antecedents of online reviews' usage and purchase influence: An empirical comparison of U.S. and Korean consumers. Journal of Interactive Marketing, 23(4), 332-340.

Park, D. H., Lee, J., \& Han, I. (2007). The effects of online consumer reviews on consumer purchasing intention: The moderating role of involvement. International Journal of Electronic Commerce, 11(4), 125-148.

Park, D. H., \& Lee, J. (2008). eWOM overload and its effect on consumer behavioral intention depending on consumer involvement. Electronic Commerce Research and Applications, 7(4), 386-398.

Park, H., \& Cho, H. (2012). Social network online communities: Information sources for apparel shopping. Journal of Consumer Marketing, 29(6), 400-411.

Peterson, R. A. (1994). A meta-analysis of Cronbach's coefficient alpha. Journal of Consumer Research, 21(2), 381-391.

Petty, R. E., \& Cacioppo, J. T. (1984). The effects of involvement on response to argument quantity and quality: Central and peripheral routes to persuasion. Journal of Personality and Social Psychology, 46(1), 69-81.

Prendergast, G., Ko, D., \& Yuen, S. Y. (2010). Online word of mouth and consumer purchase intentions. International Journal of Advertising, 29(5), 687-708.

Putrevu, S. (2001). Exploring the origins and information processing differences between men and women: Implications for advertisers. Academy of Marketing Science Review, 10, 1-14. Retrieved January 31, 2012, from http:// www.amsreview.org/articles/putrevu10-2001.pdf

Reichert, T., Heckler, S. E., \& Jackson, S. (2001). The effects of sexual social marketing appeals on cognitive processing and persuasion. Journal of Advertising, 30(1), $13-27$.

Roets, A., \& Van Hiel, A. (2007). Separating ability from need: Clarifying the dimensional structure of the need for closure scale. Personality and Social Psychology Bulletin, 33(2), 266-280.

Romani, S. (2006). Price misleading advertising: Effects on trustworthiness toward the source of information and willingness to buy. Journal of Product \& Brand Management, 15(2), 130-138.

Schindler, R. M., \& Bickart, B. (2005). Published word of mouth: Referable, consumer-generated information on the Internet. In C. P. Haugtvedt \& K. A. Machleit (Eds.), Online consumer psychology: Understanding and influencing consumer behavior in the virtual world (pp. 35-61). Mahwah, NJ: Lawrence Erlbaum Associates.

Senecal, S., \& Nantel, J. (2004). The influence of online product recommendations on consumers' online choices. Journal of Retailing, 80(2), 159-169.
Shah, J. Y., Kruglanski, A. W., \& Thompson, E. P. (1998). Membership has its (epistemic) rewards: Need for closure effects on in-group bias. Journal of Personality and Social Psychology, 75(2), 383-393.

Smith, D., Menon, S., \& Sivakumar, K. (2005). Online peer and editorial recommendations, trust, and choice in virtual markets. Journal of Interactive Marketing, 19(3), 1537.

Smith, M. R., \& Gordon, R. A. (1998). Personal need for structure and attitudes toward homosexuality. Journal of Social Psychology, 138(1), 83-87.

Sun, J., \& Wang, X. (2010). Value differences between generations in China: A study in Shanghai. Journal of Youth Studies, 13(1), 65-81.

The Retail Bulletion. (2009, October). Consumers relying on web reviews soars by $84 \%$. The Retail Bulletion: The Complete Retail News Resources. Retrieved January 10, 2012, from http://www.theretailbulletin.com/news/consumers_relying_on_web_reviews_soars_by_84_26-10$09 /$

The 2011 social shopping study. (2011, June). The e-tailing group and PowerReviews. Retrieved January 31, 2012, from http://www.powerreviews.com/assets/download/Social_Shopping_2011_Brief1.pdf

Thórisdóttir, H., \& Jost, J. (2011). Motivated closed-mindedness mediates the effect of threat on political conservatism. Political Psychology, 32(5), 785-811.

Through the eyes of the consumer: 2010 consumer shopping habits survey. (2010). ChannelAdvisor. Retrieved January 13, 2012, from http://go.channeladvisor.com/rs/channeladvisor/images/us-wp-consumer-survey-2010.pdf

Vermeir, I., \& Van Kenhove, P. (2005). The influence of need for closure and perceived time pressure on search effort for price and promotional information in a grocery shopping context. Psychology \& Marketing, 22(1), 71-95.

Wang, Y., Sun, S., Lei, W., \& Toncar, M. (2009). Examining beliefs and attitudes toward online advertising among Chinese consumers. Direct Marketing: An International Journal, 3(1), 52-66.

Webster, D. M., \& Kruglanski, A. W. (1994). Individual differences in need for cognitive closure. Journal of Personality and Social Psychology, 67(6) 1049-1062.

Xia, L., \& Bechwati, N. N. (2008). Word of mouse: The role of cognitive personalization in online consumer reviews. Journal of Interactive Advertising, 9(1), 3-13.

Yao, E., Fang, R., Dineen, B. R., \& Yao, X. (2009). Effects of customer feedback level and (in) consistency on new product acceptance in the click-and-mortar context. Journal of Business Research, 62(12), 1281-1288.

Zhu, F., \& Zhang, X. (2010). Impact of online consumer reviews on sales: The moderating role of product and consumer characteristics. Journal of Marketing, 74(2), 133-148. 